\title{
Analysis of Composite Biomass Fuels Properties
}

\author{
Edgars Čubars \\ Rezekne Academy of technologies, \\ Geo technology and Eco industry Re- \\ search center \\ Rezekne, Latvia \\ edgars.cubars@inbox.lv
}

\author{
Liena Poiša \\ Latvia university of Agriculture, \\ Jelgava, Latvia \\ lienapoisa@inbox.lv
}

\begin{abstract}
There is a growing interest about the possibility of exploiting the local biomass as an energy source. The main resource for biofuel production in Latvia is wood. Water plants, like common reed, growing in nearly all of the water reservoirs in Latvia, and all cultivate plants and residues of cereal crops, also can be good alternative for solid bio fuels production. The aim of this paper is to analyze possibilities to make composite fuels from these recourses. The study reveals research of ash content and highest burning heat value in different composite biomass fuels. It contains analysis of samples obtained from various local Latvian biomass types, i.e. reed, wood, flax spray, hay, hemp and peat, by combining them in different proportions.

The study contains optimal combining proportions of different biomass types for composite fuel production basing on the ash content and burning heat in them.

The results of the study show that the value of wood highest burning heat is higher than another biomass types like reed, peat, hay, hemp and flax spray. It means that combining of different biomass types with wood, will reduce the calorific value of composite biomass.

Also, wood is a fuel with a low ash content, and admixture of various biomass types available in Latvia, as well as admixture of coal dust to the wood in composite duels, increases ash content in the respective fuels.

In order to increase the burning heat and decrease ash content value to the optimal level and to diversify raw materials necessary for biomass fuel generating process, the authors analyze possibilities of using composite fuels by combining wood and coal dust.
\end{abstract}

Keywords - highest burning heat value, ash content, biomass, common reed, wood, peat, composite fuels, cereal crops.

\section{INTRODUCTION}

Approximately $14-16 \%$ of the total energy consumed in the world comes from renewable energy sources (RES), $10 \%$ of the total energy is generated by bioenergy [1]. Bioenergy is a type of energy produced from biomass, including thermal energy, electrical energy and various biofuels [2;1]. RES to be used in Latvia are local resources. Using such resources contributes to regional development, creation of new jobs in agriculture, forestry and processing industry; it also promotes studies of RES and related issues [3]. Forest products have the highest energy potential in Latvia (about 13,000 $\mathrm{GWh}^{*}$ year $^{-1}$ )
[4]. In addition to using traditional firewood for energy production, logging residues such as branches and stumps are increasingly used. A lot of research has been conducted in the world $[5 ; 6 ; 7]$ and in Latvia [8] related to the study of wood potential, sustainable preparation and use of wood biomass, exploration and optimisation of combustion processes. One study direction involves the use of wood growing in forests, however recent research conducted by many scientists shows that short rotation plantations on agricultural land can also be successfully used for energy production $[9,10]$. Currently, production and use of wood pellets has been growing rapidly in Latvia, mainly due to the possibility to automate heating processes. Wood pellets are one of Latvia's export goods. Wood resources are not inexhaustible, therefore there is a need for diversification of the raw material for pellet production. Various plant biomass could also be used in pellet production. One of the most suitable plants for energy production that has been widely studied in the world is reed canary grass (Phalaris arundinacea L.) $[11 ; 12,13]$. It is suitable for energy production in Latvia [9; 14;15;16]. Hemp (Cannabis sativa L.) $[17 ; 18]$ and flax (Linum usitissimum L.) [19;20] biomass, as well as peat and many other plants can also be used. Another plant that could be used for energy production in Latvia is reed (Phragmites australis (Cav.) Trin. Ex Steud.) growing in natural and artificial water bodies [21]. Research by scientists from other countries also reveals that reed can be used as a raw material for fuel production [22;23]. However, in order to use these plants in pellet production successfully, one should know their properties. Energetic properties of various plant biomass are different from those of wood; usually the heat of combustion of plant biomass is lower [24], while the ash content is higher, which can cause problems during its combustion. Therefore, the authors raise the hypothesis that plant biomass could be successfully combusted together with wood by adding it as an additional fuel. In order to see the impact of adding different plant biomass on the properties of composite pellets, the authors studied the changes in the highest heat of combustion and in the ash content depending on the amount of another fuel added to the wood. 


\section{MATERIALS AND METHODS}

The study used industrially produced wood pellets ground into powder using a mill. Various types of local biomass available in Latvia were added to the wood chips, i.e. reeds, flax shives, peat, hay, hemp fibre, as well as coal dust, that had previously been dried and ground into powder. In order to determine the ash content and highest burning heat value dependence on the amount of various types of biomass added to the wood, respective samples were prepared and analysed in the different proportions (Table 1).

TABLE 1.

Proportions of composite fuels used in the research

\begin{tabular}{|c|c|c|}
\hline \multirow{2}{*}{$\begin{array}{c}\text { Sample } \\
\text { number }\end{array}$} & \multicolumn{2}{|c|}{ Content of composite biomass } \\
\cline { 2 - 3 } & Wood, $\%$ & Admixture, Other fuel, $\%$ \\
\hline 1 & 100 & 0 \\
\hline 2 & 90 & 10 \\
\hline 3 & 80 & 20 \\
\hline 4 & 60 & 40 \\
\hline 5 & 40 & 60 \\
\hline 6 & 20 & 80 \\
\hline 7 & 0 & 100 \\
\hline
\end{tabular}

Ash content in the samples was determined using the standard method CEN/TS 14775:2004 [25]. The samples were dried at the temperature of $105^{\circ} \mathrm{C}$. They were later placed into crucibles and weighted (Fig. 1).

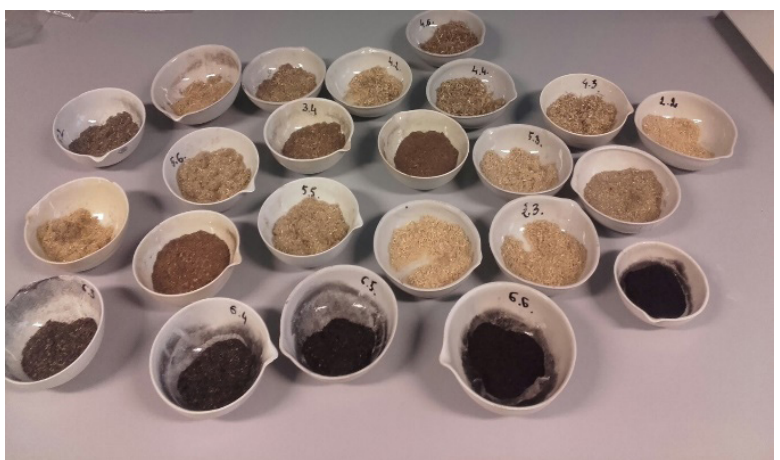

Fig. 1. Samples analysed to determine the ash content For combustion of samples the furnace "Nabertherm" was used (Fig. 2).

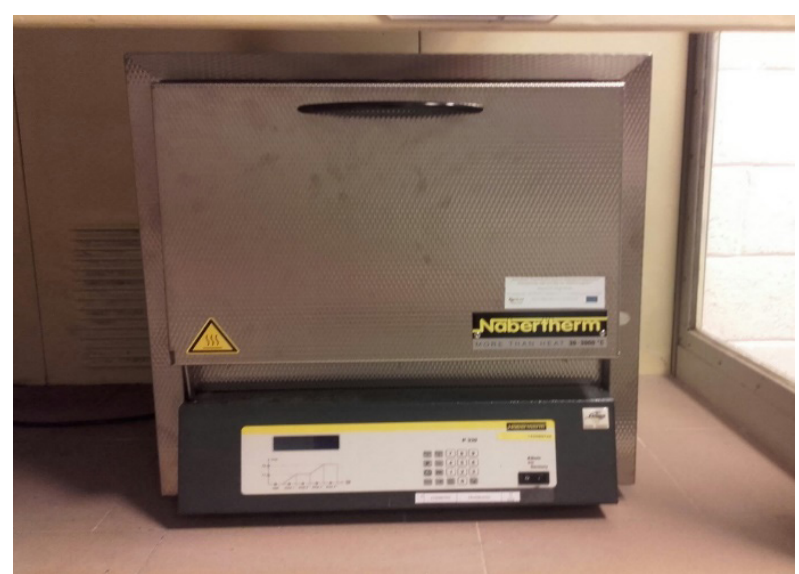

Fig. 2. The furnace used to determine the ash content After combustion in the furnace at the temperature of $550^{\circ} \mathrm{C}$ the crucibles with ash (Fig. 3) were taken out, cooled and weighted, the respective calculations of ash content were also performed. Each sample was analysed trice, measurement error assessment was also carried out [26].

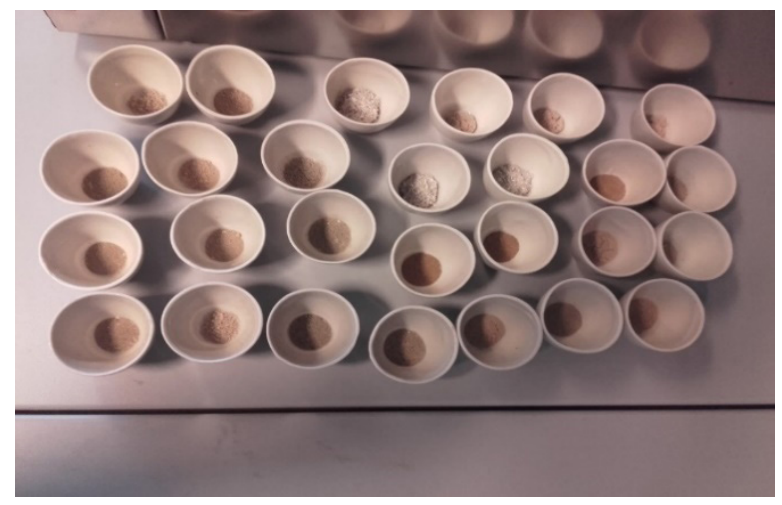

Fig. 3. Samples after combustion

Highest burning heat value in the samples was determined according to ISO 1928 using the oxygen bomb calorimeter Paar 6772 (Fig. 4).

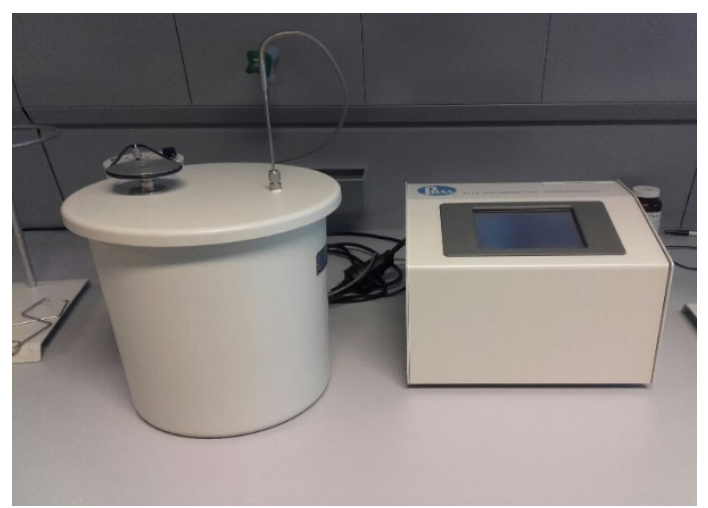

Fig.4. Oxygen bomb calorimeter Paar 6772.

The highest heat of combustion was determined using dry samples. Three parallel measurements were made for each sample and measurement errors were calculated.

\section{RESULTS AND DISCUSSION}

Within the study, industrially produced wood pellets were used and, by adding different proportions of other fuels, the highest heat of combustion and ash content was analysed. Ash is a by-product of the combustion process, mainly consisting of inorganic substances, predominantly potassium and silica [27], which are left over after the fuel combustion. High ash content in fuel is undesirable as it causes problems with automation of the process of biomass combustion [28].

According to the Standard CEN TS 14961 "Specification of solid biofuels", pellets, basing on their ash content, are divided into several classes. Industrial wood pellets we use correspond to the highest class A 0.7 (ash content below $0.7 \%$ ); as shown by the results of the analysis, the ash content there was $0.43 \pm 0.01 \%$ ( Figure 5). As revealed by the study, ash content in all other fuels added to the wood is many times higher, e.g. in coal dust it was $8.27 \pm 0.39 \%$, in reeds $2.39 \pm 0.11 \%$, which was one of the lowest results, while the ash content in flax shives was very high, i.e. 17.76 $\pm 1.05 \%$. The ash content of the peat used in the study was 
$4.13 \pm 0.21 \%$, the ash content of hay amounted to $7.73 \pm$ $0.01 \%$, for hemp it was $3.78 \pm 0.09 \%$. Such results indicate that adding any of these fuels to wood will reduce the quality of the fuel and increase its ash content, which can cause problems with burning such composite fuels in pellet boilers, and generate a large amount of combustion waste.

The research shows that, without reducing the quality class of the fuel below A 0.7 , it is possible to mix up to $10 \%$ of reed, up to $10 \%$ of peat, up to $10 \%$ of hay and up to $10 \%$ of hemp. In case $10 \%$ of flax shives and coal dust is used, the ash content will exceed the class A 0.7 , and is therefore only applicable to granules of lower classes. The use of flax shives in the production of composite fuels is not recommended at all, as their ash content is very high $(17.76 \pm 1.05 \%)$, which rapidly increases the ash content of the respective composite fuel and can cause problems with the combustion of such pellets.

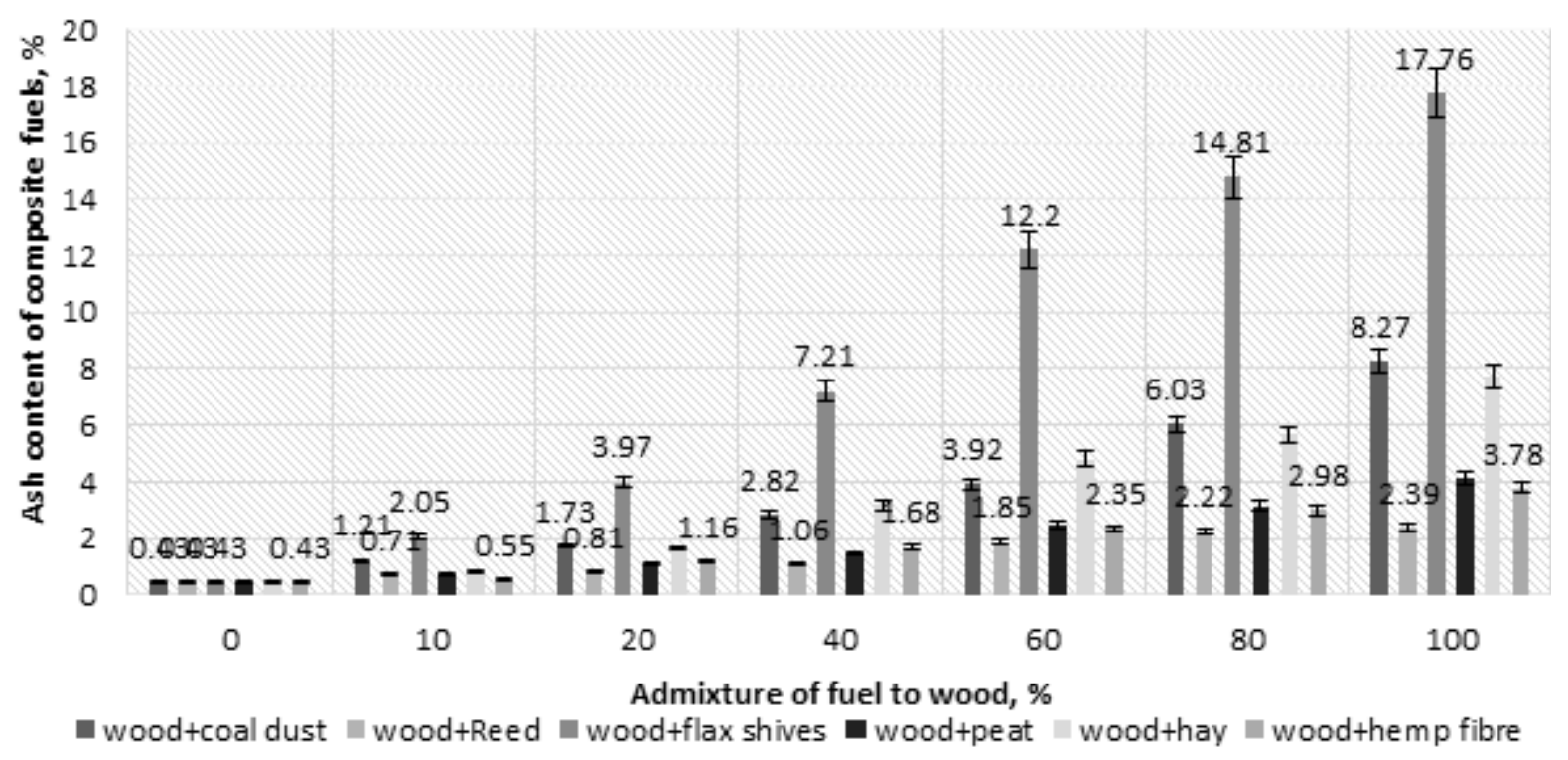

Fig.5. Ash content of composite biomas fuels

Increasing the amount of another plant biomass added to the wood reduces the quality of the fuel because the heat of its combustion decreases (see Figure 6).
This can be explained by the comparatively high ash content of different types of biomass and their elemental composition, which was not studied in this research.

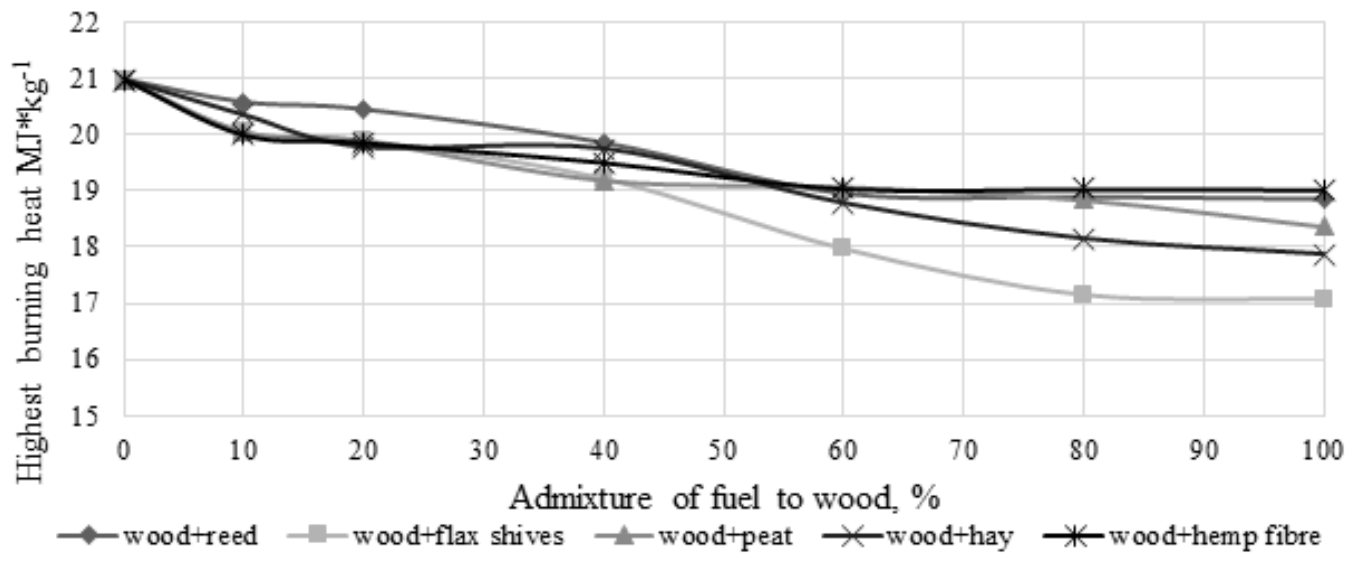

Fig. 6. Highest burning heat of composite biomas fuels

It was found that the heat of combustion of the wood was $21 \pm 1 \mathrm{MJ}^{*} \mathrm{~kg}^{-1}$, which corresponds to the values indicated on the labels of industrial pellets.

Among different types of biomass whose highest heat of combustion was determined, the lowest value was that of flax shives $\left(17 \pm 1.6 \mathrm{MJ}^{*} \mathrm{~kg}^{-1}\right)$. Given that flax shives also have a high ash content, it can be concluded that their use in composite fuels is not recommended. Other biomass types had similar values of highest combustion heat: reeds $18.9 \pm 1.1 \mathrm{MJ}^{*} \mathrm{~kg}^{-1}$, (similar results were found in another study [27]), peat $18.4 \pm 1.7 \mathrm{MJ}^{*} \mathrm{~kg}^{-1}$, hay $17.9 \pm 0.8 \mathrm{MJ}^{*} \mathrm{~kg}^{-1}$, and hemp $19.1 \pm 0.3 \mathrm{MJ}^{*} \mathrm{~kg}^{-1}$. According to the results of studies of ash content and highest heat of combustion, it can be concluded that primary biomass resources to be used in the production of composite fuels are hemp, peat and reed. Hemp's value of combustion heat is lower compared to other types of biomass, therefore its use is not recommended.

An opposite situation can be seen when adding coal dust to composite fuels. The highest heat of combustion raises rapidly when the amount added to the composite fuel increases (see Figure 7). 


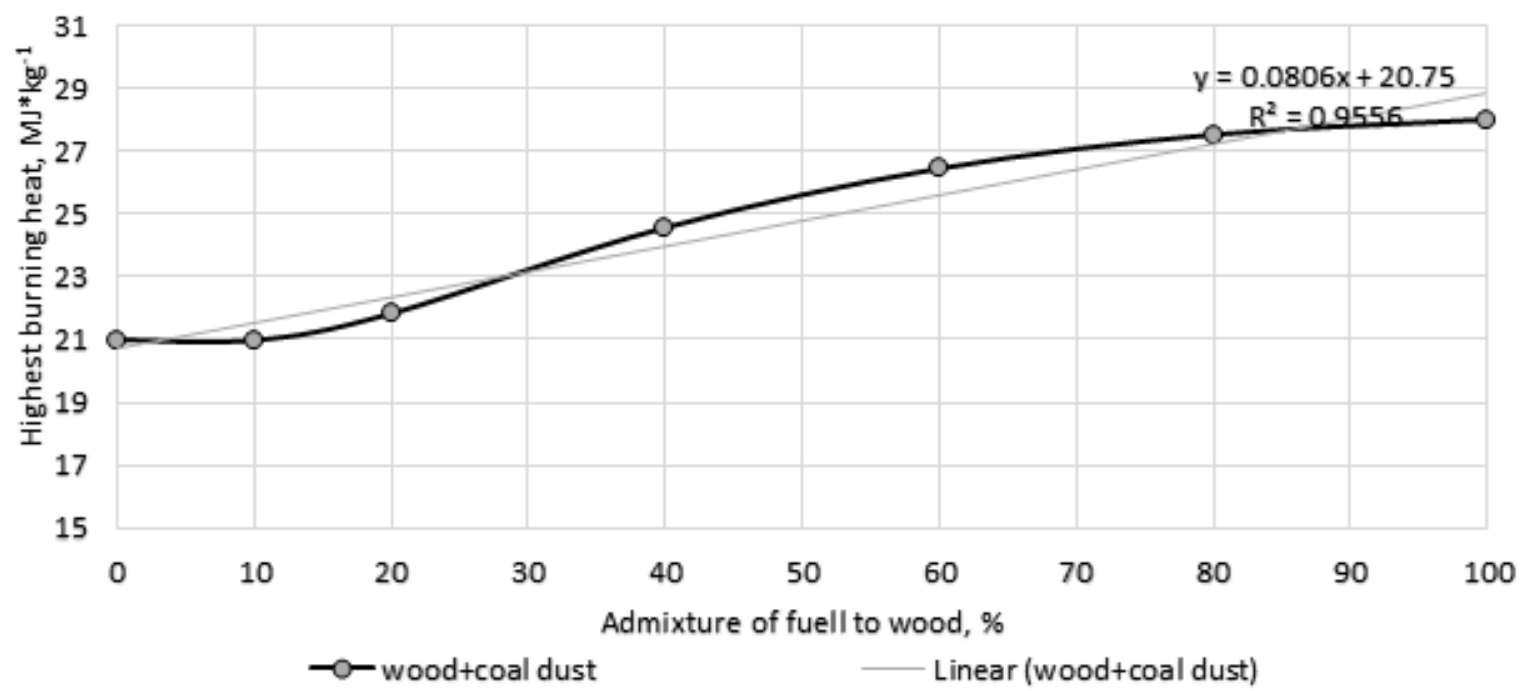

Fig.7. Highest burning heat of composit biomas fuel, wood+coal dust.

The linear equation found for the composite fuel "wood + coal dust" (Equation 1) can be used to predict the highest value of combustion heat depending on the amount of coal dust added.

$$
\mathrm{Q}=0,0806 \quad \mathrm{~m}+20,75
$$

Where: Q- highest burning heat value, $\mathrm{MJ}^{*} \mathrm{~kg}^{-1}$ m- Admixture of coal dust to wood, $\%$

Coal dust is produced as a by-product of coal handling and transportation and can be successfully used in composite fuels, increasing their value of combustion heat.

\section{Conclusions}

1. Production of composite fuels by adding different types of biomass typical in Latvia's conditions to the wood reduces their quality, i.e. increases ash content and reduces the value of combustion heat.

2. Flax shives have high ash content and a relatively low value of combustion heat, their use in composite fuels is therefore not recommended.

3. Without reducing the quality class of the fuel below A0.7 (evaluation based on the ash content), it is possible to add up to $10 \%$ of reed, up to $10 \%$ of peat, up to $10 \%$ of hay and up to $10 \%$ of hemp to the wood.

4. Adding coal dust to composite biomass fuels raises their calorific value; the highest value of combustion heat raises rapidly when the amount of coal dust added to the composite fuel increases.

\section{REFERENCES}

[1] Baskar C.,Baskar S., Dhillon R. (2012) Biomass Conversion. The Interface of Biotechnology, Chemistry and Materials Science, Springer-Verlag Berlin Heidelberg, p.91-98.

[2] Science \& Technology on Bio-hylic and Biomass Resources in China: A Roadmap to 2050 (2010) Zhang, Xinshi, Huang, Hongwen et all., pp 37-53.

[3] Broṇka A., Zvirbule-Bērziña A. (2012) Policy of the european union in the field of renewable energy resources in the context of common power industry policy. In: Proceedings of the international scientific conference Renewable energy and energy efficiency, Jelgava, p.225-230.

[4] Biomasas izmantošanas ilgtspējīibas kritēriju pielietošana un pasākumu izstrāde (2009) Adamovičs A., Dubrovskis V., Plūme I. u.c.
Valsts SIA , Vides projekti”, Rīga, 16-38. lpp.

[5] Wood2energy (2010) Jakson S.W., Rials T.G., Taylor A.M., Bozell J.G., Norris K.M., University of Tennessee, p.2-53.

[6] Wood to energy in Washington: Imperatives, Opportunities, and Obstacles to progress (2009) Mason C.L., Gustafson R., Colhoun J, Lippke B.R., Rafaeli N., University of Washington, Washington 2009, p.139-148.

[7] Mantau, U. et al. (2010) EU wood - Real potential for changes in growth and use of EU forests. Final report. Hamburg, Germany, $160 \mathrm{p}$.

[8] Latvijas atjaunojamo energoresursu izmantošanas un energoefektivitātes paaugstināšanas modelis un rīcības plāns (2009) Blumberga A., Bažbauers G. u.c. RTU, 35-37 lpp.

[9] Enerḡêtisko augu audzēšana un izmantošana (2007) Adamovičs A.,Agapovs J., Aršanica A. u. c. Valsts SIA „Vides projekti”, Rīga, 43-133. lpp.

[10] Lazdiņa D., Lazdinš A. (2011) Îscirtmeta kārklu plantācijas un to izmantošanas iespējas LVMI "Silava", Salaspils 2011, 4.-32. lpp.

[11] Tahir M., Casler M.D., Moore K.J., Brummer C. (2011) Biomass Yield and Quality of Reed Canarygrass under Five Harvest Management Systems for Bioenergy Production. In: Bioenerg. Res. 4, p.111-119.

[12] Schafer W. (2012) Fibre crops for energy production and energy saving. In: Proceedings of the international scientific conference Renewable energy and energy efficiency, Jelgava, p.7-12.

[13] Bassam N.El. (1998) Energy plant species. Their use and impact on environment and development. In:James and James(Science publisher) London, p.1-98.

[14] Poiša L., Adamovičs A. Šiaudinis G.,et.all. (2011) The chemical content of diferent energy crops. In: Proceedings of the 8th international scientific and practical conference Environment.Tehnology. Resources, Rēzeknes Augstskola, p.195.

[15] Jansone I, Gaile Z. (2012(b)) Cereal grain as alternative fuel in Latvia. In: Proceedings of the international scientific conference Renewable energy and energy efficiency, Jelgava, p.33-38.

[16] Komlajeva L.., Adamovičs A., Poiša L. (2012) Comparison of different energy crops for solid fuel production in Latvia. In: Proceedings of the International Scientific Conference „Renewable Energy and Energy Efficiency", p. 45.-50.

[17] Jankauskiene Z., Gruzdeviene E. (2012) Industrial hemp- a promising source for biomass production. In: Proceedings of the international scientific conference Renewable energy and energy efficiency, Jelgava, p.13-18.

[18] Kolodziej J., Wladyka-przybylak M., Mankowski J., Grabowska L. (2012) Heat of combustion of hemp and briquettes made of hemp shives. In: Proceedings of the international scientific conference Renewable energy and energy efficiency, Jelgava, p.163-166

[19] Komlajeva L.., Adamovičs A., Poiša L. (2012) Comparison of different energy crops for solid fuel production in Latvia. In: Proceedings of the International Scientific Conference „Renewable Energy and Energy Efficiency", p. 45.-50. 
[20] Komlajeva L,., Adamovičs A. (2012) Evaluation of flax (linum usitatissimum L.) quality parameters for bioenergy production. In: Proceedings of the 11th international scientific conference "Engineering for rural development", May 24.-25., Jelgava, Latvia p. 490-494.

[21] Kronbergs E., Šmits M. (2009) Cutting properties of common Reed biomass. In: 8th international scientific conference "Engineering for rural development”, May 28.-29., Jelgava, Latvia, p.207.

[22] Komulainen M., Simi P.,Hagelberg E., Ikonen I., Lyytinen S. (2008) Reed energy-Posibilities of using the Cammon Reed for energy generation in Southern Finland. In: Turku university of applied sciences reports 67. p.5-75.

[23] Reed up on Reed (2007) Ikkonen I., Roosaluste E., Pitkanen T.et. all. Southwest Finland regional Environment centre, Turku 2007. ,p. 5-115.
[24] Gravalos I., Xyradakis P. et all. (2016): An experimental determination of gross calorific value of different agroforestry species and bio-based industry residues, Natural Resources, 7, pp.57-68.

[25] LVS CEN/TS 14775:2004: Solid biofuels- Method for the determination of ash content.

[26] Arhipova I., Bāliṇa S.(2006) Statistika ekonomikā. Risinājumi ar SPSS un Microsoft Excel. 2.izdevums. Rīga: Datorzinību centrs, 352. lpp.

[27] Kakitis A., Ancans D., Nulle I. (2014) Evaluation of combustion properties of biomass mixtures, Engeniering for rural development, pp. 423-427.

[28] Tardenaka A., Spince B. (2006) Characterization of fuel granules and briquettes produced from fine-dispersed wastewood. In: International conference Eco-Balt 2006, Riga, Latvia, p. 37-38. 